\title{
Penerapan Model Pembelajaran Discovery Learning Untuk Meningkatkan Aktivitas Dan Hasil Belajar Siswa Pada Mata Pelajaran Kantor Depan
}

\author{
Siti Nurul Rahmah*
}

SMK Negeri 2 Singaraja

\begin{abstract}
Abstrak
Penelitian ini bertujuan untuk meningkatkan aktivitas dan hasil belajar siswa kelas XI AP-1 di SMK Negeri 2 Singaraja pada mata pelajaran kantor depan yang kompetensi dasarnya mengidentifikasi jenis-jenis kamar dan harga kamar dengan menerapkn model pembelajaran discovery learning. Penelitian ini adalah penelitian tindakan kelas (guru sebagai peneliti) dilaksanakan dalam dua siklus, terdiri dari rencana tindakan, pelaksanaan tindakan, observasi atau evaluasi dan refleksi. Subjek

Keywords:

discovery learning, aktivitas, hasil belajar, belajar kelompok, kantor depan, jenisjenis kamar, harga kamar penelitian adalah siswa kelas XI AP-1 di SMK Negeri 2 Singaraja yang berjumlah 38 orang. Data dianalisis menggunakan analisis statistik deskriptif. Berdasarkan hasil analisis data pada siklus I terlihat aktivitas siswa sebesar $68,16 \%$ berada pada kualifikasi aktif dengan kualifikasi Baik, kemudian rata-rata skor hasil belajar siswa aspek pengetahuan memperoleh skor sebesar 83, 9 aspek keterampilan sekor hasil belajar siswa sebesar 83, 5. Hasil pada siklus II, aktivitas siswa sebesar $80,53 \%$ berada pada kualifikasi sangat aktif dan rata-rata skor hasil belajar siswa,dari aspek pengetahuan sebesar 87,6, sedangkan untuk aspek keterampilan rata-rata skor hasil belajar siswa sebesar 87,8 dan seluruh siswa mencapai ketuntasan 100\% baik dari aspek sikap, pengetahuan maupun keterampilan. Jadi dapat disimpulkan Penerapan model Pembelajaran discovery learning dengan setting belajar kelompok dapat meningkatkan aktivitas dan hasil belajar siswa pada mata pelajaran kantor depan, kompetensi dasarnya mengidentifikasi jenis-jenis kamar dan harga kamar.
\end{abstract}

\section{PENDAHULUAN}

Belajar adalah proses atau usaha yang dilakukan setiap individu untuk memperoleh suatu perubahan tingkah laku baik dalam bentuk pengetahuan, keterampilan maupun sikap dan nilai yang positif sebagai pengalaman untuk mendapatkan sejumlah kesan dari bahan yang telah dipelajari (Burais, 2016). Kegiatan belajar tersebut ada yang dilakukan di sekolah, di rumah, dan di tempat lain seperti di museum, di laboratorium (Fitri, 2015). Proses belajar ini memerlukan waktu yang cukup lama dan tidak bisa instan untuk memahami materi yang dipelajari (Kristin, 2016). Istilah pembelajaran berhubungan erat dengan pengertian belajar dan mengajar. Belajar, mengajar dan pembelajaran terjadi bersama-sama untuk menumbuhkan motivasi siswa. Belajar dapat terjadi tanpa guru atau tanpa kegiatan mengajar dan pembelajaran formal lain. Sedangkan mengajar meliputi segala hal yang guru lakukan di dalam kelas.

Duffy dan Roehler mengatakan apa yang dilakukan guru agar proses belajar mengajar berjalan lancar, bermoral dan membuat siswa merasa nyaman merupakan bagian dari aktivitas mengajar, juga secara khusus mencoba dan berusaha untuk mengimplementasikan kurikulum dalam kelas.

Sementara itu pembelajaran adalah suatu usaha yang sengaja melibatkan dan menggunakan pengetahuan profesional yang dimiliki guru untuk mencapai tujuan kurikulum. Proses pemahaman siswa terhadap materi kadangkala menjadi kendala yang sangat signifikan bagi siswa dalam proses belajar. Hal

* Corresponding author. 
ini disebabkan oleh beberapa aspek baik yang berasal dari dalam diri siswa (kemauan dan kemampuan) maupun dari luar diri siswa (lingkungan, dan teman).

Untuk menumbuhkan kemampuan dan kemauan belajar dari siswa perlu adanya dorongan atau motivasi sehingga siswa bisa belajar lebih aktif dan bisa memahami apa yang dipelajari (Putrayasa, 2014). Pencapaian terhadap motivasi memang bukanlah hal yang mudah untuk diwujudkan karena motivasi memiliki 2 jenis berdasarkan asalnya. Selain itu juga perlu dipertajam mengenai seberapa besar pengaruh motivasi terhadap pembelajaran siswa dikelas maupun diluar kelas saat menerima pembelajaran dan penerapannya. Siswa memainkan peran penting untuk mempersiapkan dirinya menjadi aktor yang mampu menampilkan keunggulan dirinya sebagai sosok yang tangguh, percaya diri, kreatif, mandiri, dan profesional pada bidangnya masing-masing.

Untuk itu diperlukan adanya perpaduan antara kesiapan siswa dalam belajar dengan metode yang digunakan oleh guru dalam mengajar. Guru diharapkan memiliki kemampuan menerapkan metode pembelajaran dengan baik sehingga dapat melakukan pembelajaran yang lebih efektif. Proses belajar mengajar yang berlangsung di SMK diharapkan dapat memfasilitasi siswa untuk mencapai kompetensi yang ditargetkan oleh kurikulum. Standar proses pendidikan memiliki peranan yang sangat penting dalam upaya meningkatkan kualitas pendidikan. Guru juga merupakan komponen yang sangat penting dalam meningkatkan mutu pendidikan, agar dalam penyampaian materi sesuai dengan panduan silabus dan rancangan program pengajaran. Untuk itu diperlukan inovasi-inovasi baru yang disesuaikan dengan karakteristik siswa, sehingga siswa mampu mencapai KKM yang diharapkan oleh sekolah.

Salah satu upaya yang dapat dijadikan alternatif pemecahan masalah tersebut adalah dengan penerapan model pembelajaran yang dapat meningkatkan aktivitas dan hasil belajar siswa pada mata pelajaran kantor depan ( Front Office ) yang marupakan salah satu mata pelajaran produktif pada Program Keahlian Akomodasi Perhotelan.

Berdasarkan hasil observasi kegiatan pembelajaran pada mata pelajaran kantor depan (Front Office) khususnya pada kompetensi dasar mengidentifikasi jenis kamar dan harga kamar yang telah dilakukan oleh guru pengajar di kelas XI AP-1 SMK Negeri 2 Singaraja dan hasil wawancara beberapa siswa diperoleh bahwa sebagian besar siswa mengalami kesulitan belajar dan kurang bersemangat. Hal ini terjadi karena mata pelajaran Kantor Depan (Front Office) khususnya materi mengidentifikasi jenis kamar dan harga kamar adalah materi teori dan praktek yang sering membosankan bagi siswa bila guru selalu menerapkan model pembelajaran konvensional atau model pembelajaran langsung (direct instruction) yaitu metode ceramah baik dalam menyampaikan materi maupun penugasan, meskipun kurikulum sudah berganti menjadi kurikulum 2013, dengan pendekatan saintifik namun guru selalu memakai pola pengajaran yang sama yaitu guru sebagai pusat segalanya (teacher centered learning) sehingga menimbulkan kejenuhan pada diri siswa.

Sementara itu usaha guru dalam meningkatkan gairah belajar siswa masih sangat kurang hal ini terlihat dari metode pembelajaran yang digunakan oleh guru. Dalam kegiatan ini siswa hanya diminta untuk mencatat materi dan interaksi yang terjadi hanya satu arah dari guru ke siswa, interaksi siswa dengan guru sangat terbatas dan tidak ada interaksi yang optimal antara siswa dengan siswa yang lainnya. Akibatnya pembelajaran menjadi terpusat pada guru (Teacher center) padahal kurikulum 2013 mengamanatkan kepada guru untuk melaksanakan pemembelajaran yang berpusat pada siswa (Studen Center). Dampak dari proses pembelajaran yang berpusat pada guru ini adalah rendahnya keaktifan siswa di kelas dalam proses pembelajaran, kurangnya minat belajar dan akhirnya berdampak pada rendahnya nilai hasil belajar siswa.

Berdasarkan hasil dokumentasi nilai kognitif siswa pada materi pokok mengidentifikasi jenis kamar dan harga kamar pada mata pelajaran Kantor Depan menunjukkan bahwa nilai kognitif siswa kelas XI AP-1 Tahun Pelajaran 2016/2017, terdapat 12 orang siswa yang mendapat nilai di bawah KKM (Kretria Ketuntasan Minimal), dari 38 siswa yakni 72, sedangkan perhitungan nilai KKM yang ditetapkan di sekolah adalah 80 .

Sementara itu pengamatan aktivitas siswa di kelas juga menunjukkan siswa terlihat pasif yaitu hanya mendengarkan apa yang disampaikan oleh guru. Hal lain yang dapat diamati adalah tanggung jawab siswa dalam menyelesaikan tugas kelompok dan presentasi hasil kerja kelompok juga masih rendah. Aktivitas siswa ketika berdiskusi, siswa tidak benar-benar menggunakan waktunya untuk berdiskusi dan mengerjakan lembar kerja siswa dengan baik sehingga ketika tahap presentasi siswa yang ditunjuk mengalami kesulitan menyampaikan jawabannya dengan baik di depan kelas.

Dilihat dari keaktifan siswa di kelas, diketahui bahwa dari jumlah siswa kelas XI AP-1 yang terdiri dari 38 orang hanya $20 \%$ siswa ( 8 orang) yang aktif bertanya, itupun hanya siswa tertentu saja. Sementara siswa lainnya hanya mendengarkan dan menunggu penjelasan guru. Sedangkan keaktifan untuk menjawab pertanyaan guru juga sangat rendah. 
Oleh karena itu, pemilihan model pembelajaran yang efektif sebagai bagian dari upaya peningkatan proses pembelajaran yang masih kurang seperti di atas sangat dibutuhkan. Model pembelajaran aktif adalah suatu model pembelajaran yang memungkinkan siswa belajar dengan mudah, menyenangkan, dan dapat tercapai tujuan pembelajaran sesuai dengan harapan (Mardiyah, 2011).

Model pembelajaran yang diupayakan sebagai solusi untuk mengatasi permasalahan tersebut adalah model pembelajaran penemuan atau discovery learning. Model discovery learning (pembelajaran penemuan) merupakan bentuk pembelajaran dengan cara mengembangkan kegiatan belajar siswa aktif yang menggunakan proses mental untuk menemukan suatu konsep atau prinsip (Rismayani, 20130. Dengan menggunakan model discovery learning proses pengajaran akan berpindah dari teacher center ke student center (Rohim, 2013). Model pembelajaran discovery learning merupakan model pembelajaran melalui penemuan siswa secara mandiri (Widiadnyana, 2014). seorang yang mengajar dengan model ini harus menjalankan tugas apa yang harus siswa lakukan, apa tujuan dari tugas yang diberikannya itu, lalu kemana mereka harus mencari informasi, mengolah, membahas, dalam kelompoknya masing-masing.

Berdasarkan kondisi tersebut di atas, maka untuk menyelesaikan permasalahan tersebut diperlukan penelitian tindakan kelas sebagai upaya perbaikan pelaksanaan proses pembelajaran dan peneliti tertarik untuk mengambil judul "Penerapan Model Pembelajaran Discovery Learning untuk Meningkatkan Aktivitas dan Hasil Belajar Siswa pada Mata Pelajaran Kantor Depan Kelas XI AP-1 Semester Ganjil SMK Negeri 2 Singaraja Tahun Pelajaran 2016/2017."

Penelitian ini memiliki tujuan sebagai berikut. (1) Meningkatkan aktivitas belajar siswa kelas XI AP1 di SMK Negeri 2 Singaraja pada mata pelajaran kantor depan yang kompetensi dasarnya mengidentifikasi jenis-jenis kamar dan harga kamar dengan menerapkn model pembelajaran discovery learning. (2) Meningkatkan hasil belajar siswa kelas XI AP-1 di SMK Negeri 2 Singaraja pada mata pelajaran kantor depan yang kompetensi dasarnya mengidentifikasi jenis-jenis kamar dan harga kamar dengan menerapkn model pembelajaran discovery learning.

\section{METODE PENELITIAN}

Jenis penelitian yang digunakan dalam penelitian ini adalah penelitian tindakan kelas (PTK) atau disebut classroom action research. Penelitian tindakan kelas adalah suatu bentuk penelitian yang bersifat reflektif dengan tindakan-tindakan tertentu agar dapat memperbaiki atau meningkatkan praktek-praktek pembelajaran. Bentuk penelitian tindakan kelas yang akan digunakan dalam penelitian ini adalah guru sebagai peneliti, yaitu guru dalam hal ini penelitian berperan sangat penting dalam proses PTK. Dalam bentuk ini tujuan utama PTK adalah untuk meningkatkan praktek-praktek pembelajaran di kelas dimana guru terlibat secara penuh dalam tahap perencanaan tindakan, pelaksanaan tindakan, observasi dan evaluasi, serta tahap refleksi.

Desain penelitian dilakukan beberapa tahapan yaitu tahap perencanaan tindakan, pelaksanaan tindakan, observasi dan evaluasi, serta tahap refleksi yang dilaksanakan pada akhir siklus, yang mana masing-masing siklus alur kegiatannya sama yaitu membahas satu sub pokok bahasan pada proses pembelajaran (keaktifan dan hasil belajar siswa) diamati dengan tujuan untuk melihat kelemahan serta kelebihan yang terjadi dalam tindakan sebelumnya, kemudian memperbaikinya pada tindakan atau di siklus berikutnya sehingga kelemahan pada siklus berikutnya dapat ditekan seminimal mungkin untuk memperoleh hasil yang optimal. Masing-masing tahap dipaparkan sebagai berikut:

1. Perencanaan Tindakan

Sebelum melaksanakan tindakan, ada beberapa hal yang harus dilakukan antara lain: Melakukan pengamatan lapangan dengan maksud untuk mengamati secara langsung proses belajar mengajar di kelas, menganalisis kurikulum sekolah yaitu Kompetensi Inti (KI) dan Kompetensi Dasar (KD), silabus, menyusun Rencana Pelaksanaan Pembelajaran (RPP), LKS membuat alat evaluasi dan merencanakan pelaksanaan penggunaan model pembelajaran discovery learning pada kelas XI AP-1 dalam proses belajar mengajar pada mata pelajaran Kantor Depan yang dirancang dalam 2 siklus yaitu: a) Siklus I terdiri dari 2 kali kegiatan tatap muka dengan pembahasan“Jenis-jenis kamar beserta fasilitas dan harga kamar, berikut contoh jenis-jenis kamar dan harganya, dan b) Siklus II terdiri dari 2 kali kegiatan tatap muka. Materi berdasarkan hasil diskusi peserta didik dan merupakan materi dari siklus I.

2. Pelaksanaan Tindakan

Untuk mengetahui secara jelas deskripsi pelaksanaan tindakan pada masing masing siklus, selanjutnya akan diuraikan sebagai berikut: tahap perencanaan dan tahap pelaksanaan siklus I. Obsevasi dan Evaluasi

Observasi dilakukan pada saat proses belajar mengajar terlaksana, komponen atau aspek yang diobservasi meliputi; (1) kehadiran peserta didik dalam mengikuti PBM, (2) kemampuan peserta didik 
dalam bertanya (3) kemampuan peserta didik dalam menjawab pertanyaan. (4) ketepatan siswa dalam menjawab (5) keterampilan siswa dalam berkomunikasi.

4. Refleksi

Refleksi dilakukan pada akhir siklus sebagai acuan dalam refleksi ini adalah hasil observasi dan tes hasil belajar serta hasil angket terhadap siswa dengan melihat perubahan-perubahan serta tanggapan siswa terhadap interpretasi tiap kelompok..Hasil refleksi ini digunakan sebagai dasar untuk memperbaiki serta menyempurnakan perencanaan dan pelaksanaan tindakan pada siklus berikutnya.

Penelitian ini akan dilakukan dalam mata pelajaran Kantor Depan pada semester ganjil tahun pelajaran 2016/2017 di SMK Negeri 2 Singaraja. Penelitian ini dilakukan selama 4 bulan yaitu mulai bulan Agustus sampai bulan Nopember 2016. subyek penelitian adalah peserta didik kelas XI AP-1 yang berjumlah 38 siswa, yang terdiri dari 18 siswa laki-laki dan 20 siswa perempuan.

Data yang akan dikumpulkan pada penelitian ini adalah data mengenai hasil pengamatan terhadap (1) hasil belajar, (2) aktivitas belajar. Berdasarkan hasil data yang diperlukan, maka instrument yang digunakan dan pelaksanaan pengumpulan data tersebut sebagai berikut:

a. Hasil Belajar

Data hasil belajar siswa merupakan penilaian terhadap hasil/ karya siswa yang berupa nilai dari tes mengenai konsep materi yang dipelajari baik tes lisan maupun tes terulis. Data ini dikumpulkan pada akhir setiap siklus. dengan tujuan untuk mengetahui sejauh mana keberhasilan tindakan yang dilakukan dalam meningkatkan pemahaman konsep siswa terhadap materi yang diberikan. Instrumen ini disusun oleh peneliti dengan berpedoman terhadap tujuan pengajaran yang telah dirumuskan.

b. Aktivitas Belajar

Data aktivitas belajar siswa dikumpulkan dengan teknik observasi. Instrument yang digunakan adalah lembar pengamatan atau lembar yang telah dipersiapkan. Dalam hal ini diberlakukan lembar pengamatan saat diskusi dan rubrik penilaian saat presentasi. Semua aspek aktivitas ini di observasi selama proses pembelajaran berlangsung. Lembar observasi aktivitas belajar terdiri dari 5 item penilaian memiliki rentang 1 sampai 4. Masing-masing item memiliki skor minimal 1 dan maksimal 4 . Berdasarkan hal tersebut maka dapat ditentukan bahwa skor maksimalnya adalah 20 dan skor minimalnya adalah 4 .

c. Angket Respon Siswa

Angket merupakan data penunjang yang digunakan untuk mengumpulkan informasi terkait dengan respon atau tanggapan siswa terhadap penerapan model pembelajaran discovery learning. Data ini menggunakan skala Kurt yang terdiri dari lima pilihan jawaban dengan pilihan sangat setuju (SS), setuju (S),) Ragu-ragu (RR) tidak setuju, (TS), dan sangat tidak setuju (STS)..Untuk pernyataan masingmasing /item diberikan skor yaitu $: \mathrm{SS}=5 ; \mathrm{S}=4 ; \mathrm{RR}=3 \mathrm{TS}=2$; STS = 1.Angket diberikan 20item sehingga skor terbesar $=100$ dan terkecil $=20$.

Data hasil belajar siswa meliputi aspek sikap, pengetahuan dan keterampilan dianalisis secara deskriptif kuantitatif Sedangkan kualifikasi hasil belajar siswa dikatakan berhasil apabila berada pada kualifikasi baik yang diperoleh sesuai KKM.

\section{ANALISIS DAN PEMBAHASAN}

Hasil pada siklus I terlihat pada aktivitas siswa sebesar $68,16 \%$ berada pada kualifikasi aktif dan skor hasil belajar siswa dari aspek sikap 100\% dengan kualifikasi Baik, kemudian aspek pengetahuan memperoleh skor sebesar 83,9 dengan jumlah siswa 26 orang siswa yang mencapai ketuntasan dan 12 siswa yang belum mencapai ketuntasan, sedangkan untuk aspek keterampilan sekor hasil belajar siswa sebesar 83,5 dengan jumlah siswa yang mencapai ketuntasan, 33 siswa dan 5 siswa yang belum mencapai ketuntasan. Hal ini disebabkan belum adanya pemahaman siswa terhadap penerapan model pembelajaran discovery learning. Selain itu pada pembelajaran siswa masih kurang disiplin. Siswa masih bekerja secara individu atau kerjasama dalam kelompok kurang dalam menyelesaikan permasalahan yang diberikan oleh guru. Selain itu, kemampuan siswa dalam kelompok rata-rata sama sehingga kelompok bersifat homogen. Siswa juga belum mampu menguraikan proses dalam memecahkan masalah, dan siswa juga belum terbiasa untuk mengemukakan pendapat, menjawab pertanyaan, maupun bertanya tentang materi yang belum dipahami. Hal ini menyebabkan siswa terlihat kurang aktif dalam pembelajaran di kelas. Kendala-kendala yang didapatkan kemudian didiskusikan oleh guru/peneliti dengan teman sejawat dalam kegiatan refleksi untuk dicarikan solusinya. Melalui kegiatan refleksi ini, disepakati beberapa solusi yang akan dilaksanakan untuk mengatasi kendala-kendala dalam pembelajaran.

Melihat hambatan yang dihadapi pada siklus I maka dapat diberikan upaya perbaikan dengan cara sebagai berikut: Pertama, menjelaskan kembali langkah-langkah dalam penerapan model pembelajaran discovery learning Kedua memotivasi siswa supaya dapat berpikir kritis dan keatif dalam mengikuti 
pembelajaran. Ketiga, memberikan bimbingan kepada siswa dalam proses pemahaman materi yang disampaikan.

Hasil pada siklus II, aktivitas siswa sebesar $80,53 \%$ berada pada kualifikasi sangat aktif dan ratarata skor hasil belajar siswa,dari aspek pengetahuan sebesar 87,6, sedangkan untuk aspek keterampilan rata-rata skor hasil belajar siswa sebesar 87,8 dan seluruh siswa mencapai ketuntasan.100\% baik dari aspek sikap, pengetahuan maupun keterampilan

Hasil perhitungan aktivitas belajar siswa pada siklus I sebesar $68,16 \%$ berada pada kualifikasi aktif sedangkan hasil perhitungan aktivitas belajar pada siklus II sebesar $80,53 \%$ yang berada pada kualifikasi sangat aktif sehingga dapat disimpulkan bahwa terjadinya peningkatan sebesar $12,37 \%$. Suasana pembelajaran pada pelaksanaan siklus II menjadi lebih aktif bila dibandingkan dengan siklus I dan siswa semakin aktif dalam menyampaikan hasil diskusi kelompoknya.

Skor hasil belajar siswa pada siklus I a) aspek sikap 100\% dengan kualifikasi baik dengan uraian 2 orang/siswa memperoleh nilai 4 dengan predikat Sangat Baik dan 36 orang memperoleh nilai 3 dengan predikat Baik , pada siklus II terjadi peningkatan bahwa siswa yang memperoleh nilai 4 sebanyak 3 siswa, dengan predikat Sangat baik, 35 siswa memperoleh nilai 3 kualifikasi baik b) aspek pengetahuan memperoleh sekor sebesar 83,9 sedangkan pada siklus II diperoleh skor hasil belajar siswa sebesar 87,6 sehingga mengalami kenaikan sebesar 3,7\%, sedangkan untuk aspek keterampilan sekor hasil belajar siswa pada siklus I sebesar 83,5, dan skor hasil belajar siswa pada siklus II sebesar 87,8 sehingga mengalami kenaikan sebesar 4,3\% Hal ini menunjukkan bahwa dengan menerapkan model pembelajaran discovery learning dapat meningkatkan aktivitas dan hasil belajar siswa.

\section{KESIMPULAN}

Berdasarkan analisis terhadap data hasil penelitian tindakan kelas ini dapat disimpulkan hal-hal sebagai berikut:

1. Model Pembelajaran discovery learning dengan setting belajar kelompok dapat meningkatkan hasil belajar siswa pada mata pelajaran kantor depan, yang kompetensi dasarnya mengidentifikasi jenisjenis kamar dan harga kamar di kelas XI AP-1. Dilihat dari skor hasil belajar siswa pada siklus I dari aspek pengetahuan memperoleh skor sebesar 83,9 sedangkan pada siklus II diperoleh skor hasil belajar siswa sebesar 87,6 sehingga mengalami kenaikan skor hasil belajar sebesar 3,7\% sedangkan untuk aspek keterampilan bila dilihat dari skor hasil belajar siswa pada siklus I sebesar 83,5 sedangkan pada siklus II diperoleh skor hasil belajar siswa sebesar 87,8 sehingga mengalami kenaikan skor hasil belajar sebesar 4,3\% dan keseluruhan siswa mencapai ketuntasan.belajar $100 \%$ baik dari aspek sikap, pengetahuan maupun keterampilan.

2. Penerapan Model Pembelajaran discovery learning dengan setting belajar kelompok dapat meningkatkan aktivitas belajar siswa pada mata pelajaran Kantor Depan kompetensi dasarnya mengidentifikasi jenis-jenis kamar dan harga kamar. Dilihat dari hasil perhitungan aktivitas belajar siswa pada siklus I sebesar $68,16 \%$ berada pada kualifikasi aktif sedangkan hasil perhitungan aktivitas belajar pada siklus II sebesar $80,53 \%$ yang berada pada kualifikasi sangat aktif sehingga dapat disimpulkan bahwa terjadinya peningkatan sebesar $12,37 \%$.

Berdasarkan hasil penelitian dan pembahasan yang telah dilakukan serta temuan-temuan yang diperoleh selama penelitian maka dapat diajukan beberapa saran guna meningkatkan kualitas pembelajaran Kantor Depan dikemudian harinya sebagai berikut:

a. Bagi siswa, agar selalu aktif dalam pembelajaran discovery learning untuk melatih dan meningkatkan hasil belajar baik dalam kelompok untuk membantu memecahkan permasalahan belajar teman maupun permasalahan belajar individu.

b. Bagi guru, disarankan agar menerapkan pembelajaran discovery learning sebagai pertimbangan dan perbaikan pada proses belajar mengajar karena dapat membantu meningkatkan aktivitas dan hasil belajar siswa, selain itu agar kegiatan pembelajaran dapat berhasil dengan baik, maka seorang guru hendaknya selalu aktif dalam melibatkan siswa selama kegiatan pembelajaran berlangsung

c. Pembelajaran Kantor Depan hendaknya bervariasi dan tidak menoton sehingga hasil pembelajaran dapat lebih maksimal

d. Bagi sekolah, diharapkan dapat menjadikan penelitian ini sebagai pedoman untuk meningkatkan aktivitas dan hasil belajar siswa khususnya pada mata pelajaran Kantor Depan. 


\section{DAFTAR PUSTAKA}

A.M. Sardiman. 2011. Interaksi dan Motivasi Belajar Mengajar. Jakarta: Rajawali

Anita, Lie. 2008. Kooperatif Learning. Jakarta: PT Grasindo

Anggoro, B.S., 2016. Meningkatkan Kemampuan Generalisasi Matematis Melalui Discovery Learning dan Model Pembelajaran Peer Led Guided Inquiry. Al-Jabar: Jurnal Pendidikan Matematika, 7(1), pp.1120.

Arikunto, Suharsimi.2001. Dasar Dasar Evaluasi pendidikan. Jakarta: Bina Aksara

Burais, L., Ikhsan, M. and Duskri, M., 2016. Peningkatan kemampuan penalaran matematis siswa melalui model Discovery Learning. Jurnal Didaktik Matematika, 3(1), pp.77-86.

Fitri, M., 2015. Pengaruh model pembelajaran discovery learning terhadap hasil belajar siswa pada materi pokok suhu dan kalor. INPAFI (Inovasi Pembelajaran Fisika), 3(2).

Kristin, F., 2016. Analisis Model Pembelajaran Discovery Learning Dalam Meningkatkan Hasil Belajar Siswa Sd. Jurnal Pendidikan Dasar Perkhasa, 2(1), pp.90-98.

Mawaddah, S. and Maryanti, R., 2016. Kemampuan Pemahaman Konsep Matematis Siswa SMP dalam Pembelajaran Menggunakan Model Penemuan Terbimbing (Discovery Learning). EDU-MAT, 4(1).

Putrayasa, I.M., Syahruddin, S.P. and Margunayasa, I.G., 2014. Pengaruh Model Pembelajaran Discovery Learning Dan Minat Belajar Terhadap Hasil Belajar IPA Siswa. MIMBAR PGSD Undiksha, 2(1).

Pratiwi, F.A. and Rasmawan, R., 2014. Pengaruh Penggunaan Model Discovery Learning Dengan Pendekatan Saintifik Terhadap Keterampilan Berpikir Kritis Siswa SMA. Jurnal Pendidikan dan Pembelajaran, 3(7).

Qomariyah, N., 2014. Penerapan Model Pembelajaran Guided Discovery untuk Meningkatkan Keterampilan Proses Sains Siswa SMP Kelas VII. PENDIDIKAN SAINS, 2(01).

Rismayani, N.L., 2013. Penerapan Model Pembelajaran Discovery Learning Untuk Meningkatkan Hasil Belajar Pkn Siswa. Jurnal Pendidikan Kewarganegaraan Undiksha, 1(2).

Rosarina, G., Sudin, A. and Sujana, A., 2016. Penerapan Model Discovery Learning Untuk Meningkatkan Hasil Belajar Siswa Pada Materi Perubahan Wujud Benda. Jurnal Pena Ilmiah, 1(1), pp.371-380.

Rohim, F. and Susanto, H., 2012. Penerapan Model Discovery Terbimbing Pada Pembelajaran Fisika Untuk Meningkatkan Kemampuan Berpikir Kreatif. UPEJ Unnes Physics Education Journal, 1(1).

Rudyanto, H.E., 2016. Model discovery learning dengan pendekatan saintifik bermuatan karakter untuk meningkatkan kemampuan berpikir kreatif. Premiere Educandum: Jurnal Pendidikan Dasar dan Pembelajaran, 4(01).

Sulistyowati, N., Widodo, A.T.W.T. and Sumarni, W., 2012. Efektivitas model pembelajaran guided discovery learning terhadap kemampuan pemecahan masalah kimia. Chemistry in education, 1(2).

Widiadnyana, I.W., Sadia, I.W. and Suastra, I.W., 2014. Pengaruh model discovery learning terhadap pemahaman konsep IPA dan sikap ilmiah siswa SMP. Jurnal Pendidikan dan Pembelajaran IPA Indonesia, 4(1). 